\title{
Level of Environmental Awareness of Students in Republic of Serbia
}

\author{
Milutin Maravić ${ }^{1, *}$, Stanko Cvjetićanin ${ }^{2} \&$ Sonja Ivković ${ }^{1,3}$ \\ ${ }^{1}$ Faculty of Sciences, University of Novi Sad, Novi Sad, Serbia \\ ${ }^{2}$ Faculty of Pedagogy in Sombor, University of Novi Sad, Sombor, Serbia \\ ${ }^{3}$ Faculty of Environmental Governance and Corporate Responsibility, University Educons, Sremska Kamenica, \\ Serbia \\ *Corresponding author: Faculty of Sciences, University of Novi Sad, Trg Dositeja Obradovića 3, Novi Sad, Serbia. \\ Tel: 381-6323-4117. E-mail: milutin.maravic@gmail.com
}

Received: March 22, 2014

Accepted: April 17, 2014

Online Published: May 7, 2014

doi:10.5430/wje.v4n3p13

URL: http://dx.doi.org/10.5430/wje.v4n3p13

\begin{abstract}
The aim of this research was developed in order to determine and analyze the level of environmental awareness of students from primary and secondary schools. Environmental awareness is an essential product of environmental education. Conducted research included analytical and descriptive method. The research instrument was the survey designed for purpose of the research. There were 198 students of primary and secondary school involved in the survey which included 28 questions. Following statistic parameters were used for results analysis: mean value, standard deviation (SD) and coefficient of variation (CV). The existence of difference between opinions of students (statistic significance of differences between mean values) was determined by variance analysis (ANOVA) or using independent t-test.
\end{abstract}

Keywords: environmental awareness; education system; environmental protection; primary and secondary schools

\section{Introduction}

Environmental issues have reached important point in $21^{\text {st }}$ century and they are still rising. Global warming, greenhouse effect, ozone layer depletion, environmental degradation, nuclear pollution, reduction of green areas, the extinction of some plant and animal species are some of the most important environmental problems of today (Bonnett, 2007). Increasing problems opened many questions without answers. These questions are related to environmental education, including such education through school curricula (Milotojevič, 2005). In 1989, UNESCO promoted environmental literacy as a fundamental goal in environmental protection. Environmental literacy included contents, skills and processes which students could conduct on daily basis. In other words, they can live in accordance with these elements (Marić-Jurišin, 2013). Because of its content, environmental education has a multidisciplinary feature. The purpose of environmental education is to help students to build environmental attitudes through the system of environmental protection (Uzin \& Keles, 2012). According to Carvalho de Suosa, Sevilla-Pavon and Seiz-Ortiz (2012) the entire education is environmental and it should include environmental dimension during the teaching process. Horka and Vystričil Markova (2013) argued that education should be aimed to attitudes and behaviours which will determine the way of social and economic development in accordance with sustainable development.

Environmental education presents only a part of a whole. It is a part of total development of every person. Unfortunately, it seems that we are in an era of contradiction, because it seems that environmental education used to be much more prevalent in the development of personality. Today, it remains suppressed and marginalized while it is constantly mentioned (Andevski, 2006). Effective environmental education is possible only through mutual support and complementarity of formal and informal education (Soykan \& Atasoy, 2012). According to Mazoloumiyan, Shobeiri, Farajollahib and Mohamadic (2012) environmental education is the most effective method for protection of our environment and it is aimed to finding of best methods for information presentation and quality determination. On the other hand, it can be a basis for improvement of the environmental awareness of the entire society. 
Environmental awareness is the main product of environmental education. There are different definitions of such concept which is justified since the environmental awareness is a dynamic dimension. This dimension changes every day as the man itself, including changes in the nature and their mutual relationship (Djordjević, 2002). The term of environmental awareness included values, readiness to become responsible for other people and quality of their environment. Therefore, the environment is not something concrete and given but it is changeable category which develops abstractly and where potential damages of the environment mostly threaten all mankind (Andevski, 2006).

Today there are many information of global warming, recycling, irrational use of natural resources, extinction of certain plant and animal species, organic diet, ecotourism. All of that are elements of the environmental awareness (Goleman, 2010).

Forming of environmental awareness about environmental problems is not spontaneous. It is conducted by socio-economic, political, cultural processes which define the level of risk (un)acceptable for (concrete and/or global) society in a certain moment (Jehlicka, Sarre \& Podaba, 2005). Hannigan (2006) claimed that environmental awareness presents the part of broader philosophy of social movement aimed at preserving and improving the natural environment, both in the interest of the individual, and in the interest of civilization and its survival as a whole. Environmental awareness of the individual includes environmental knowledge, environmental values and environmental behavior. All of these components are necessary for truly understanding, respect and practicing of environmentally friendly way of life (Milotojevič, 2005).

Pušić and Pajvanović (2010) in their research of relationship of Vojvodina citizens toward environmental problems showed that environmental knowledge of respondents are mostly localized and limited to phenomena from their everyday environment. They emerge from concrete environmental condition of towns where respondents live. According to research by Petrović and Vukelić (2013) concern of Serbian citizens is also encouraged by perception of threat for the environment, for which the majority of respondents considered that higher than in developed Western European countries in relation to the former socialist republics, while there is even number of respondents who believe that the situation in Serbia is getting worse, or the same as in other countries in the region.

Conducted survey in the Republic of Croatia indicated on a low level of environmental awareness and need for introduction of system education for sustainable development on all education levels and increasing of awareness using media. Such awareness is related to ways of environment preservation on national, regional and local level (Afić, 2002). Ozden (2008) conducted research on environmental awareness and behavior of students in Turkey. Obtained results showed that students from urban areas have more positive attitudes on environmental awareness than those from rural areas. Results of the research on environmental awareness of European citizens, made by Ruben and Ángeles (2011) showed that citizens of Scandinavian countries have the higher level of environmental awareness, while the lowest level is indicated in citizens from former SSSR republics and states from East Balcan.

\section{Research Methodology}

\subsection{Aim of the Research}

The aim of this research developed in need to determine and analyze the level of environmental awareness (awareness, attitudes, knowledge) of students from primary and secondary schools (high-schools and agricultural vocational schools) as a main product of environmental education. After determination of the level of environmental awareness of students, the work included the suggestion for possibilites to extend Chemistry curricula in primary and secondary schools using environmental education contents.

\subsection{Research Tasks}

To analyze environmental awareness, attitudes, behaviours and knowledge of students of primary and secondary schools according to the analysis in order to determine the level of environmental awareness.

\subsection{Research Methods and Techniques}

The conducted research used analytical and descriptive method. Research techniques are following: field research, combined techniques, action researchs. The survey designed for the purpose of this research was used as a research instrument. It included 28 questions on which students could respond with answers: Yes; No; I don't know. These questions were divided in three groups:

1. Questions on environmental awareness (5 questions),

2. Questions on environmental attitudes and behaviour (7 questions), 
3. Questions on environmental knowledge (16 questions).

Following statistic parameters were used for analysis of the survey: mean value, standard deviation (SD) and coefficient of variation (CV). The existence of difference between opinions of students (statistic significance of differences between mean values) was determined by variance analysis (ANOVA) or using independent t-test.

\subsection{The Sample}

The survey included 198 students as respondents in Novi Sad (Serbia), of which 71 students were from primary school, 60 students were from high-school while 67 students were from the agriculture school.

\section{Results and Discussion}

At the level of primary school and general education, environmental contents are mainly studied integrative within all teaching subjects (with the exception of subjects of social and artistic orientation). During the first cycle of primary education in the Republic of Serbia, environmental contents are often included in almost all teaching subjects using correlation. However, they are mainly present in subjects such as the world around us in first and second grade, Nature and Society in third and fourth grade of primary education. Environmental contents in higher grades of primary education, from fifth to eighth grade are present in subjects: Biology, Geography, Chemistry and Physics.

As a separate teaching subject, Ecology firstly appeared in secondary schools as a subject in some secondary vocational schools. It should be mentioned that environmental contents are also studied through general subjects (Biology, Geography, Chemistry, Physics) in many areas of work and education profiles. The status of subjects through which environmental contents are studied depends mainly on the vocational occupation for which students are educated. High-school belongs to general education schools so the Ecology is not present as a separate subject but environmental contents are presented through subjects of natural sciences: Chemistry, Biology, Physics and Geography. Depending on areas of styding, these subjects are closely connected to environmental contents.

Table 1 presents differences in the level of environmental awareness of students from primary school and high school.

Table 1. Differences in The Level of Environmental Awareness of Students from Primary School and High-School

\begin{tabular}{lcccccccc}
\hline School & $\mathrm{N}$ & Sc.at level & Mean value & SD & CV & t & p & comment \\
\hline Primary & 71 & 649 & 24.11 & 8.99 & .37 & \multirow{2}{*}{2.53} & .06 & $\mathrm{p}>.05$ \\
High-school & 60 & 771 & 28.56 & 8.12 & .28 & & & \\
\hline
\end{tabular}

According to results of t-test analysis, there is no statistically significant different between level of environmental awareness of students from primary and high-school ( $\mathrm{p}>.05$ ). Comparising mean values, standard deviations (SD) and coefficients of variation (CV) for the level of environmental awareness of students of primary school and high-school showed that there is no significant difference. However, students of high-school have better result, higher level of knowledge (771) than students of primary school (649) regarding environmental awareness, attitudes and behavior. This was an expected result. Different teaching curriculum (which provides higher level of environmental knowledge), greater interest of students for environmental problems, more frequent social actions and education programs in non-government sector are factors which contributed to better awareness of high-school students about nature of main environmental issues in the society today.

High vocational schools in education system of the Republic of Serbia cover great number of areas of work with wide scope of education profiles. Areas of work which are studied in secondary schools are following: Agriculture, Geodesy and Construction, Manufacturing and Food Processing, Chemicals, metals and graphic; Mechanical Engineering and Metalworking, Textile and Leather; Geology, Mining and Metallurgy, Electrical, Transportation, Forestry and wood processing, Health care and Social welfare, Economics and Law; Culture-arts, Commerce and tourism. Four-year education profiles in almost all areas of work have content related to ecology which is studied through common education subjects (Chemistry, Physics, Biology, Geography). Environmental content are studied through vocational subjects in education profiles which are more directly related to ecology and environmental protection. Three-year education profiles in almost all areas of work have environmental content mostly studied through common education subjects (Chemistry, Physics, Geography), while the subject named Ecology and environmental protection appeared for the first time in such curricula. Most of education profiles study this subject during one school year. 
Table 2 presents differences in the level of environmental awareness of students from primary and agriculture vocational school.

Table 2. Differences in the Level of Environmental Awareness of Students from Primary and Agriculture Vocational School

\begin{tabular}{lcccccccc}
\hline School & N & Sc.at level & Mean value & SD & CV & t & p & comment \\
\hline Primary & 71 & 649 & 24.11 & 8.99 & .37 & -80 & .88 & $\mathrm{p}>.05$ \\
Agriculture & 67 & 661 & 24.48 & 8.86 & .36 & & & \\
\hline
\end{tabular}

Table 2 indicates that the standard deviation for primary school is slightly higher (8.99) than for secondary vocational school (8.86), while the coefficient of variation is on the same level. Results of the analysis using t-test between environmental awareness of students of primary and secondary agriculture school showed that there is no significant statistic difference $(\mathrm{p}>.05)$. Students of agriculture school have slightly better result, higher level of knowledge (661) than primary school students (649) regarding environmental awareness, attitudes and behavior, which is an alarming data because of profession for which they are educated. Nearly half of students of agriculture school showed total unawareness (or disinformation) of actual environmental issues (environmental awareness, attitudes and knowledge), which implies on conclusion that there is a very low level of knowledge and interest for this topic among respondents. This data is concerning since students from agriculture school (considering their future profession) should represent people with higher level of education and broader scope of interest for protection and preservation of the environment.

Table 3 presents differences in the level of environmental awareness of students from high-school and secondary agriculture school.

Table 3. Differences in the Level of Environmental Awareness of Students from High-school and Secondary Agriculture School

\begin{tabular}{lcccccccc}
\hline School & $\mathrm{N}$ & Sc.at level & Mean value & SD & CV & t & p & comment \\
\hline High school & 60 & 771 & 28.56 & 8.12 & .28 & 1.76 & .08 & $\mathrm{p}>.05$ \\
Agriculture & 67 & 661 & 24.48 & 8.86 & .36 & &
\end{tabular}

The analysis using independent t-test showed that there is no significant statistic difference ( $\mathrm{p}>.05)$ between the level of environmental awareness (awareness, attitudes and knowledge) of students from high-school and agriculture school. Obtained results showed that students of high-school have a higher level of environmental awareness, opinions and knowledge (771) than students from secondary agriculture school (661). This was unexpected result during preparation and conduction of the survey. Students of secondary agriculture school have higher number of common and vocational education subjects related to protection and preservation of the environment.

Statistic relevance (Table 4) of obtained differences between mean values of levels of environmental awareness of students was defined using the variance analysis (ANOVA).

Table 4. Statistic Importance of Obtained Differences between Mean Values of Levels of Environmental Awareness of Students

\begin{tabular}{lcccccc}
\hline Source of Variation & SS & df & MS & F & P-value & F crit \\
\hline Between Groups & 328.40 & 2 & 164.20 & 2.19 & .12 & 3.11 \\
Within Groups & 5858.07 & 78 & 75.10 & & & \\
Total & 6186.47 & 80 & & & & \\
\hline
\end{tabular}

Since the calculated value of the parameter $\mathrm{F}$ is smaller than critical one, the zero hypothesis remains. In other words, mean values of samples (surveyed students) are not significantly different.

Regarding the level of environmental awareness, attitudes and behavior of students from primary, secondary agriculture school and high-school and conducted analysis, the following can be concluded:

1. Level of environmental awareness, attitudes, behavior and knowledge of surveyed students from primary and secondary school is low.

2. Level of environmental awareness, behavior, knowledge of high-school students is much higher than the level of environmental awarenesss of students from primary school and secondary agriculture school; 
3. Teaching curricula and education programs of the Republic of Serbia include many differences in subjects and demands for environmental protection, aims, tasks and environmental contents.

\section{Conclusion and Recommendation}

Results on low awareness, attitudes and knowledge of students from the Republic of Serbia represent alarming information. Since the used questionnaire included questions about knowledge and awareness of current environmental issues, it can not be confirmed that the only cause of low results lies in a lack of professional knowledge about environmental issues. Survey results showed that proenvironmental behavior in students was not initiated by knowledge on environmental issues and causes of their existence, or critical attitude for environmental situation.

There are more argues about problems of environmental protection and their significance during last years in Serbia. However, public debates are not and can not be the only way on which individual can and should be informed. Environmentally responsible person forms himself/herself from earliest youth. Considering the seriousness of environmental problems, the introduction of environmental education in all education levels is needed. Introduction of such concept in education would encourage young people to think about this important issue and it would shape values and behavior in proenvironmental direction.

\section{References}

Afić, K. (2002). Environmental awareness-assumption of solving environmental problems (Ekološka svijest-pretpostavka rješavanja ekoloških problema). Ekonomski pregled, 53(5-6), 578-594.

Andevski, M. (2006). Ecology and Sustainable Development. Novi Sad: Cekom books.

Bonnett, M. (2007). Environmental Education and the Issue of Nature. Journal of Curriculum Studies, 39(6), 707-721. http://dx.doi.org/10.1080/00220270701447149

Carvalho de Sousa, A., Sevilla-Pavon, A., \& Seiz-Ortiz, R. (2012). Autonomy and ICT in environmental education. Procedia-Social and Behavioral Sciences, 46, 1343-1347. http://dx.doi.org/10.1016/j.sbspro.2012.05.299

Djordjević, J. (2002). New environmental ethics and environmental protection. Teme, 26(2), 235-244. Retrieved from http://scindeks-clanci.ceon.rs/data/pdf/0353-7919/2002/0353-79190202235D.pdf

Goleman, D. (2010). Ecological intelligence (Ekološka inteligencija). Beograd: Geopoetika.

Hannigan, J. A. (2006). Environmental Sociology (2nd. ed.). London \& New York: Routledge.

Horka, H., \& Vystričil Markova, P. (2013). From Environmental Education to Biophiled Orientation of Education. Procedia-Social and Behavioral Sciences, 89, 328-331. http://dx.doi.org/10.1016/j.sbspro.2013.08.855

Jehlicka, P., Sarre, P., \& Podaba, J. (2005). The Czech Environmental Movement's knowledge interests in the 1990s: compatibility of Western influences with pre-1989 perspectives. Environmental Politics, 14(1), 64-82. http://dx.doi.org/10.1080/0964401042000310187

Marić-Jurišin, S. (2013). Ecological literacy through the prism of the educational system of the Republic of Serbia-representation and processing (Ekološko opismenjavanje kroz prizmu vaspitno-obrazovnog sistema Republike Srbije-zastupljenost i obrada). Pedagoška stvarnost, 59(1), 55-66.

Mazoloumiyan, S., Shobeiri, S. M., Farajollahib, M., \& Mohamadic, M. (2012). Blended e-Learning: a new approach to environmental education of Iran high schools. Procedia-Social and Behavioral Sciences, 47, 1216-1220. http://dx.doi.org/10.1016/j.sbspro.2012.06.803

Milotojevič, V. (2005). Ecological Culture. Niš: Fakultet zaštite na radu.

Ozden, M. (2008). Environmental awareness and attitudes of student teachers: an empirical research. International Research in Geographical an Environmental Education, 17(1), 40-55. http://dx.doi.org/10.2167/irgee227.0

Petrović, M., \& Vukelić, J. (2013). Environmental protection in Pančevo and Bor: Challenges of participatory approach to environmental governance. Belgrade: Institute for Sociological Research Faculty of Philosophy University of Belgrade.

Pušić, Lj., \& Pajvanović, A. (2010). Relation of Citizens of Vojvodina according to environmental problems (Odnos građana Vojvodine prema ekološkim problemima). Socijalna ekologija, 19(3), 273-292. Retrieved from 
http://hrcak.srce.hr/index.php?show=clanak\&id_clanak_jezik=96557

Ruben, M., \& Ángeles, B. (2011). Environmental awareness and paper recycling. Cellulose Chemistry and Technology 44(10), 431-449.

Retrieved from http://www.cellulosechemtechnol.ro/pdf/CCT10\%282010\%29/p.431-449.pdf

Soykan, A., \& Atasoy, E. (2012). Historical development of non-formal environmental education in Turkey. Procedia-Social and Behavioral Sciences, 46, 736-743. http://dx.doi.org/10.1016/j.sbspro.2012.05.190

Uzin, F. V., \& Keles, O. (2012). The effects of nature education project on the environmental awareness and behavior. Procedia-Social and Behavioral Sciences, 46 , 2912-2916. http://dx.doi.org/10.1016/j.sbspro.2012.05.588 